\title{
Error analysis of undergraduate students' writing performances: IELTS-based activities
}

\author{
Novrika Nartiningrum ${ }^{*}$ (ำ https://orcid.org/0000-0002-7700-4320 \\ Pusfika Rayuningtya ${ }^{2}$ https://orcid.org/0000-0003-4533-3629 \\ Diska Fatima Virgiyanti ${ }^{3}$ https://orcid.org/0000-0002-3442-8246 \\ ${ }^{1}$ Language Center, University of Muhammadiyah Malang, Indonesia \\ ${ }^{2}$ Sekolah Tinggi Tehnik STIKMA Internasional Malang, Indonesia \\ ${ }^{3}$ Faculty of Tarbiyah, University of Darussalam Gontor Ponorogo, Indonesia
}

\begin{abstract}
As English as a Foreign Language (EFL) students, it is expected that they should have good ability in four skills of English, including writing skill. However, errors are still found in students' written works. This paper examines the different types of writing errors made by 10 Indonesian undergraduate students who were enrolled in an IELTS preparation class. Descriptive qualitative research was employed in this study. The errors in the term papers were identified and classified accordingly. The students' works were assessed based on four aspects: task achievement, cohesion and coherence, lexical resource, grammatical range, and accuracy. The result of this study showed that the highest percentage of students' errors was in terms of lexical resource and grammatical range (accuracy), followed by three other common errors: singular or plural, word choice, and punctuation. Regarding to the task achievement, in Task 1 , most of the students addressed the task but they didn't cover all the information needed. While in Task 2 , some students presented clear opinions but with limited and inadequately developed ideas and gave no conclusion. Furthermore, for the results of cohesion and coherence in Task 1, most students showed good logical sequence and overall progression but with faulty cohesion devices. However in Task 2, some students presented either incoherent or illogical ideas or information. These results contribute as fruitful insights for language learners who want to enhance the IELTS comprehension, particularly writing performance.
\end{abstract}

\section{ARTICLE INFO \\ Keywords:}

error analysis; IELTS-

based activities; students'

writing performances

\section{Article History:}

Received: 25 February 2021

Revised: 28 March 2021

Accepted: 05 April 2021

Published: 12 April 2021

How to Cite in APA Style:

Nartinigrum, N.,

Rayuningtya, P., \&

Virgiyanti, D. F. (2021).

Error analysis of

undergraduate students'

writing performances:

IELTS-based activities.

Journal of Educational

Management and

Instruction, 1(1), 19-27

\section{Introduction}

Writing is a productive language skill that needs to be mastered by undergraduate students (Christensen et al., 2011; Nugroho \& Rahmawati, 2020). It is often mentioned that writing is considered as the most difficult skill to be mastered by the students, regardless of the level of education (Sulistyo et al., 2019). Richards et al. (2002: 303) mentioned that writing is the most difficult for second language and foreign language learners. Writing can be broad-defined in terms of what is being produced in written form; sentence, paragraph and essay. In this study, writing essay is taken as the main focus because it has been conducted by the students since the high school level until higher education.

With the importance of English in today's world, the four skills - which includes writing - are often used for assessing someone's competence in English in the form of standardized tests such as IELTS (Lam et al., 2018). In IELTS, the type of writing being 
tested is essay writing. According to British Council website, IELTS, abbreviation of the International English Language Testing System, is the world's most popular English language proficiency test for higher education and global migration. In addition, IELTS is recognized by many institutions such as educational, government, office, and professional institutions (Hyatt, 2013). It means that IELTS is a test which is needed for continuing the study or job all over the world.

Assessing writing in IELTS covers three aspects namely coherence and cohesion, lexical resource, and grammatical range and accuracy (Arcuino, 2013). Achieving the three aspects in IELTS writing is not an easy job. In other words, everyone who needs to take IELTS in order to graduate or continue their studies will be required to be able to write decently. For example, in order to enroll in a good university abroad, students are usually demanded to have band 6.5 or 7 minimum in IELTS (To et al., 2013). On the other hand, if we look at the real life conditions, most undergraduates in Indonesia still have errors in their writings since English is positioned as foreign language in Indonesia. The less promotion of English for international communication in Indonesia leads to the majority of people being handicapped about the language itself (Lauder, 2008). This has an impact on the writing skill of the students which is far from showing satisfactory results. One of the most apparent problems in English writing is the lack of vocabulary (Fareed, et.al, 2016; Rahmatunisa, 2014). This problem leads to the word repetition that hinders creativity (Rahmatunisa, 2014). The concept of grammar which depends on time signals in English becomes the next struggle most students face. Many researches show that students' error writing is dominated by grammar (Huy, 2015; Rahmatunisa, 2016; Fareed, et al., 2016).

Aside from the two problems above-mentioned, there are many other prominent problems found in students' writing. It seems that the error cannot be eliminated by being careful (Nartiningrum \& Nugroho, 2020; Taylor, 1997). Moreover, the errors that second language students made can be the major factor in the feedback system in the teaching and learning process through the examinations and tests (Al-Khresheh, 2016). Therefore, due to plenty of errors found in students' writing, it has become the focus of research since decades ago. Error analysis is described as a set of procedures to identify, describe and explain learners' errors (Ellis \& Barkhuizen, 2005, cited in Amiri \& Puteh, 2017). Error analysis can provide a good methodology for investigating L2 learners' errors because it plays a fundamental role in investigating, analysing, and categorising errors made by L2 learners (Al-Khresheh, 2016). Hence, error analysis has been conducted with extensive subjects and population to investigate the students' writing error.

A study conducted by Al Zoubi (2018) investigated errors made by English language major students in writing an essay. The results showed that the most common errors found were in terms of word choice and spelling, while the least common errors were in terms of possessive usage and pluralism. It was also indicated in the study that there were many reasons which caused the errors. One reason that was revealed in the study was the lack of teachers' competence in language teaching or unsatisfactory learning materials. Another study conducted by Nurhayati \& Nurdini (2019) examined the errors on the independent writing task of TOEFL iBT candidates. Grammar, mechanics and content were three categories of errors found in the study. The three most frequent errors in terms of grammar made by the candidates were in agreement, verb and sentence structure. In terms of content, the errors were in the forms of reusing the sentences from the question, inability in addressing the topic of the task well and missing the conclusion part.

In a similar direction, the study of Al-Khasawneh (2014) that was conducted to analyze the English paragraphs by 26 undergraduate students from non-English speaking environments also showed several writing errors. The highest rate was coming from the wrong use of article, which was followed by wrong use of prepositions and 
subject-verb agreement in second and third position. Al-Khasawneh (2014), then, linked the result with the lack of second and foreign knowledge from the non-native speakers. In terms of writing performance, deficient vocabulary knowledge and the language structure rules became the main problems as why the students made incomprehensible sentences. Moreover, the similar studies have been also conducted by revealing the error analysis in writing English language and resulted in identic findings (Khansir, 2013; Kharmilah \& Narius, 2019; Wu \& Garza, 2014).

The previous research has been studying about the errors in writing. Various categories of errors were also found. However, errors analysis that employs the categories in IELTS writing rubric is still unexplored in Indonesian context. Therefore, the present study aims to investigate students' errors in IELTS essay writings by utilizing the categorization of errors in IELTS rubric of writing. The results of this study are fruitful as reference for EFL teachers, especially the ones who specify their teaching writing in IELTS materials. In order to ensure the objectives, the present study is guided under two research questions: (1) what errors are made by students in utilizing lexical items and sustaining accurate use of grammar in the essays? (2) what errors are made by students in fulfilling the task and maintaining coherence and cohesion throughout the essays?

\section{Method}

\section{Research context and participants}

Descriptive qualitative method was employed in this study. Data in the present study were 10 term papers from undergraduate students in the Communication Science department, University of Darussalam Gontor (UNIDA) Ponorogo East Java Province Indonesia. It was mandatory for Communication Science students to pass the minimum IELTS band score. Therefore, the teaching and learning activities on writing in the English course focused on consistent application of writing essays. By the end of the English course, students were expected to be able to write good essays.

\section{Instrument and data collection}

The data were collected from the mid-term exam. The students were asked to write Task I and Task II of the IELTS writing test for 60 minutes. Task 1 of IELTS writing asks the test takers to write a summary of at least 150 words about a particular graph (line, bar or pie graph), chart, table or process about how something is done or how something works. Different from task 1, Task 2 of IELTS writing commands the test participants to write an essay in response to a question. The participants should write at least 250 words. Afterwards, writing rubric for IELTS was utilized to analyse students' writing errors. The table below shows the aspects evaluated from the students' writing.

Table 1. Evaluation Aspects for Students' Writing

\begin{tabular}{ll}
\hline Band Score & Description of Category \\
\hline Task Achievement & $\begin{array}{l}\text { fully developed response with key points of the information, clear } \\
\text { purpose of the task, consistent and appropriate tone, clear overview of } \\
\text { the graph/picture/trends with appropriate selected information }\end{array}$ \\
$\begin{array}{l}\text { Cohesion and } \\
\text { Coherence }\end{array}$ & $\begin{array}{l}\text { good paragraph, logical sequence of ideas and information, error-free } \\
\text { usage of cohesive devices, unerring referencing }\end{array}$ \\
$\begin{array}{l}\text { Lexical Resource } \\
\text { wide range of vocabulary, accurate choice of words, natural control of } \\
\text { lexical features, correct use of collocation, exact spelling, right word } \\
\text { formation }\end{array}$ \\
$\begin{array}{l}\text { Grammatical Range } \\
\text { and Accuracy }\end{array}$ & $\begin{array}{l}\text { accurate and flexible usage of structure, wide range of structure, } \\
\text { precise control of grammar and punctuation }\end{array}$ \\
\hline
\end{tabular}




\section{Data analysis}

In analysing the data, steps of error analysis specified were implemented. First, every essay was checked in the word level and sentential level. Coding categories were generated based on all essays samples. Second, the total of errors were counted and converted into percentages to investigate the occurrence. The result which focuses on the error analysis concerning the language aspect is presented in Table 2 and 3. Table 2 displays the language errors in Task 1 while table 3 presents the language errors in Task 2. For other aspects such as task achievement, coherence and cohesion, interpretive analysis was implemented. Categories in Table 1 were the categories found in the writing rubric for IELTS. Some samples of sentences from every category were displayed in order to emphasize the categories.

\section{Results}

Table 2 shows the result of error analysis on Task 1 . There are 15 types of errors found in students' essays about a graph. The errors listed in the table are in terms of lexical resource as well as grammatical range and accuracy. Information about numbers of errors and their percentage is covered in the table.

Table 2. Analysis of Errors in Task 1

\begin{tabular}{clcc}
\hline Item & Types of Errors & $\begin{array}{c}\text { Numbers of } \\
\text { Errors }\end{array}$ & Percentage \\
\hline 1. & Capitalization & 48 & 36.6 \\
2. & Word Choice & 20 & 15.2 \\
3 & Punctuation & 14 & 10.6 \\
4 & Singular-Plural & 12 & 9.1 \\
5 & Deletion & 8 & 6.1 \\
6 & Spelling & 7 & 5.3 \\
7 & S/V Agreement & 5 & 3.8 \\
8 & Word Form & 4 & 3.0 \\
9 & Insertion & 3 & 2.2 \\
10 & Sentence Structure & 3 & 2.2 \\
11 & Article & 2 & 1.5 \\
12 & Pronoun & 2 & 1.5 \\
13 & Collocation & 1 & 0.7 \\
14 & Verb form & 1 & 0.7 \\
15 & Preposition & 1 & 0.7 \\
\hline
\end{tabular}

Table 2 shows that the types of errors found in task 1 are mostly in the word level such as capitalization, word choice, pronoun, deletion, punctuation, singular/plural, article, insertion, spelling, collocation, verb form and preposition. Only few errors are in the sentence level for instance word form, sentence structure and subject-verb agreement. The percentage also depicts that the numbers of errors done by the students are more in the word level rather than in sentence level.

As can be noticed in Table 2, the type of errors that has the highest percentage is capitalization (36.6). Most students often missed to write capital letters in the beginning of their sentences. Word choice (15.2) comes second in the percentage, followed by punctuation (10.6), singular/plural (9.1), deletion (6.1), spelling (5.3), subject-verb agreement (3.8), word form (3.0) sentence structure and insertion (2.2), pronoun and article (1.5) also collocation, verb form and preposition (0.7).

Similar to the result of task 1, the type of errors found in task 2 are mostly in the word level (spelling, collocation, word choices, singular/plural, punctuation, capitalization, insertion, deletion, article, verb tense and verb form). Few errors in the sentence level mentioned in table 3 are word form, sentence structure and subject-verb 
agreement. From the two tables, it can be concluded that students mostly made mistakes in word level rather than in sentential level.

Table 3. Analysis of Errors in Task 2

\begin{tabular}{clcc}
\hline Item & Types of Errors & $\begin{array}{c}\text { Numbers of } \\
\text { Errors }\end{array}$ & Percentage \\
\hline 1. & Capitalization & 42 & 24.6 \\
2. & Singular / Plural & 26 & 15.2 \\
3 & Word Choice & 24 & 14.04 \\
4 & Punctuation & 18 & 10.5 \\
5 & Spelling & 15 & 8.7 \\
6 & Deletion & 11 & 6.4 \\
7 & Sentence Structure & 7 & 4,09 \\
8 & Insertion & 7 & 4.09 \\
9 & S-V Agreement & 7 & 4.09 \\
10 & Article & 5 & 2.92 \\
11 & Word Form & 5 & 2.92 \\
12 & Verb form & 2 & 1.2 \\
13 & Verb tense & 1 & 0.7 \\
14 & Collocation & 1 & 0.7 \\
\hline
\end{tabular}

The highest percentage of error in task 2 is capitalization (24.6) which is followed by singular/plural (15.2). The third and fourth places are word choice (14.4) and punctuation (10.5). Spelling (8.7), deletion (6.4), sentence structure (4.09), insertion (4.09), S-V agreement (4.09), article (2.92), word form (2.92), verb form (1.2), verb tense (1.2), and collocation (0.7) mentioned as the other errors the students made in task 2. In both tasks, the students' error is mostly dominated by capitalization; while it does not seem to occur in other errors.

The data above shows that in terms of grammatical range and accuracy, students' errors are mostly about capitalization. Students missed the correct use of capital letters in both task 1 and task 2 . In the aspect of lexical resources, students mostly have problems in choosing the appropriate words for expressing their ideas as word choice comes second (task 1) and comes third (task 2) in errors' percentage.

Other evaluation aspects for students' writing, as presented by IELTS rubric, are task achievement and cohesion and coherence. In task 1 , in which the students are asked to write a summary of a graph, chart, or table in 150 words, most of the students addressed the task but they didn't cover all the information needed. If they did, they included irrelevant, unclear and repetitive details of information. Many students did not have a clear overview of the paragraph. However, some students gave clear overview of paragraph and appropriate detail information. In this task, students are given a graph about the number of computer and internet users in nine different Arab countries and they were required to write the report describing the information. For instance, student A only covered 2 countries who use the highest number of computers and internet. From four main paragraphs, two of them described the United Arab Emirates as the country with the highest computer and internet users and one paragraph described Kuwait as the country with the second highest.

In task 2, in which the students wrote an essay in response to a question, the result is more diverse. Few students did not state any opinion towards the question given. Some students presented clear opinions but with limited and inadequately developed ideas and gave no conclusion, while the others addressed the task clearly but presented no conclusion. In task 2 , students are required to present an argument whether they agree or disagree about the topic of 'When a country develops its technology, the traditional skills and ways of life die out. It is pointless to try and keep them alive' along with examples and relevant evidence. For example, student B presented his clear side that he disagreed with 
the topic but he did not elaborate further why he chose to disagree. Due to the language structure error found in his writing, it is very hard to identify where his idea leads to. Student B tried to link the topic with the condition in class where students are more adaptable to the modern learning approach but at the same time teacher needs to utilize the use of traditional learning media such as songs. The brief explanation given by student B does not represent the arguments asked in Task 2.

This paragraph discusses the results regarding the cohesion and coherence in both Task 1 and Task 2. In Task 1, most students showed good logical sequence and overall progression but with faulty cohesion devices. The minority presented ideas with some organization but lack of clear overall progression. Some students use cohesive devices and logical ideas organization effectively. As an illustration, student $\mathrm{C}$ has good logical sequence and overall progression but it includes faulty cohesive devices in conjunction and pronoun. It was found in the sentence "Many people use the computer and internet in his daily activities". The pronoun his to replace many people is inaccurate as his refers to a singular male person. The faulty conjunction usage is found in these following sentences "The second countries in the Arab World must using the internet and computer is Kuwait. but the people more using the computer than the internet". But is used for contrasting the idea while the second sentence above is the additional idea that continues the first sentence.

In Task 2, some students presented both incoherent or illogical ideas and information. Sometimes it is found with no clear throughout progression or no concluding paragraph. No logical information and inaccurate cohesive devices were also recognized in some students' writing. However, few students demonstrated effective cohesive devices with clear overall progression and logical arranged paragraphs. Student D presents his opinion about the topic and gives the information supported. However, the writing does not show clear paragraph progression and coherent arranged ideas. In the first paragraph, the student explains about the ethnic diversity in Indonesia which is supported by incoherent and unrelated ideas towards the topic. He generalized that all Sundanese people have fair skin color which are different from Javanese people who have brown skin because they live in low land. Right after that, the second paragraph mentions several examples of technology development. The flow between the first and second paragraphs is not natural as Student $\mathrm{C}$ does not give accurate paragraph transition words and phrases. In the third paragraph, the student connects the use of technology with the traditional way of life. He gives the example of greeting as a traditional way of life which can be put into action through texting by saying greeting or salam in the beginning of the text. In this case, providing the example of using greeting or salam in the beginning of the text is irrelevant because greeting is not related to the traditional way of life.

\section{Discussion}

The analysis of errors made by students in their IELTS essay writing gives insights about how their language proficiency shows urgent issues in their academic writing. In terms of language aspects, the students had problems understanding the use of capital letters. It is proven by capitalization as the highest number of errors in both tasks. Quite similar result was found by Amiri \& Puteh (2017) who discovered that capitalization was one of common errors performed by the students in terms of language errors. Four common errors mentioned in their study were sentence structure, articles, punctuation and capitalization. In line with the result of their study, the present study learned that students had difficulties with punctuation since it was also included as one of four most common errors in this article.

Moreover, the results of the present study agree with a study conducted by Divsar and Heydari (2017) which noticed that the most frequent errors in the learner corpora were word choice errors. Identical results were revealed in the present study where word choice was involved in three most frequent errors performed by the students. 
Repeated errors in word choice suggest that students still needed sufficient vocabularies in writing essays.

Regarding the task achievement, the results were quite varied. In task 1, most students were able to address the task. However, some information was still missing from their essays. Many students also gave irrelevant, unclear and repetitive information. Still, there were some students who were able to write clear overviews of the paragraph and appropriate information. Students' writings for task 2 less achieved the task's requirements. There were students who successfully addressed the task clearly but missed to conclude the ideas. Then, there were some students who presented clear opinions yet failed to develop the ideas and were unable to draw conclusions. Few students even did not express their positions on the matter given.

These practices could be linked to students' difficulties in understanding the graph, deciphering the meaning of the statements given in task 2 or their low motivation in writing. This is in line with a study done by Salima (2012) who mentioned that students' deficiencies in writing skill are the result of their poor background knowledge of the target language, lack of practices and low motivation in writing. Poor background knowledge in target language might lead to students' difficulties in understanding the task (Nugroho et al., 2021). Furthermore, lack of practices and low motivation in writing caused the students to write irrelevant, unclear and repetitive information.

Then, most students' ability in maintaining coherence and cohesion in task 1 was quite good since most of the students were able to show good logical progression although errors in the use of cohesion devices still exist. For example, the cohesion device errors are in the forms of reference errors and conjunction errors. This is in line with Indriyani's (2018) study which found that types of cohesive device errors in high school students' writing were reference and conjunction.

Regarding coherence and cohesion in Task 2, some students already use cohesive devices appropriately. However, most of them still missed this in writing paragraphs. Then, students presents information and ideas but these are not arranged coherently and there is no clear progression in the response. Most students also did not write the conclusion paragraph because they were too focused on writing the introduction and main paragraph. This is in line with Amiri \& Puteh (2017) and Alberth (2018) that students may stray away from points stated in thesis statements, provide detailed and information irrelevant to topic sentences or introduce a new idea in the conclusion step.

\section{Conclusion}

The in-hand study examines the different types of writing errors made by 10 Indonesian undergraduate students who were enrolled in an IELTS preparation class. The data analysis shows that the students' types of errors with the highest percentages found in IELTS writings (task 1 and task 2) are similar. Four most common errors regarding lexical resource and grammar appropriateness found in the sample essays are; capitalization, word choice, punctuation and singular or plural. The teacher is advised to pay more attention to these types of errors. The teacher is suggested to pay more attention to students' use of capitalization. It is also suggested to train the students about the correct use of capital letters. Students are also expected to understand more grammatical rules such as subject-verb agreements, punctuations, and articles. Future research may employ more sample writings in order to obtain better understanding on university students' errors in IELTS writing tests.

All in all, the result of this present study is expected to contribute to the body knowledge of Error analysis to indicate students' error, particularly in IELTS writing. By knowing the students' errors, it helps the teachers to decide the teaching approach to minimize problems in the future. Also, this study can provide insightful information for the future researchers who will conduct the research in the scope of Error Analysis. Examining the cause errors made by students can be an interesting subject to be 
explored. Future researchers are also recommended to deal with more essay samples, various proficiency levels of EFL learners and other skills that are being measured in IELTS.

\section{Acknowledgements}

Gratitude and acknowledgement go to all Indonesian EFL learners who were willingly to be the participants in this research.

\section{References}

Alberth. (2018). Indonesian high school student motivational orientations for learning english as a foreign language: Some preliminary findings. Electronic Journal of Foreign Language Teaching, 15(2), 304-321.

Al-Khasawneh, F.M. (2014). Error Analysis of Written English Paragraphs by Jordanian Undergraduate Students: A Case Study. International Journal of English Language, Literature and Humanities, 2(8), 85-100.

Al-Khresheh, M.H. (2016). A Review Study of Error Analysis Theory. International Journal of Humanities and Social Science Research, 2, 49-59.

Al-Zoubi, S.M. (2018). The Significance of Error Analysis in Written Production: A Case Study of Ajloun National University Students. International Journal of English Language and Literature Studies, 7(4), 150-159.

Amiri, F., \& Puteh, M. (2017). Error Analysis in Academic Writing: A Case of International Postgraduate Students in Malaysia. Advances in Language and Literary Studies, 8(4), 141-145.

Arcuino, C. L. T. (2013). The relationship between the Test of English as a Foreign Language (TOEFL). The International English Language Testing System (IELTS) scores and academic success of international Master's students, Colorado State University.

Christensen, D., Barnes, J., \& Rees, D. (2011). Improving The Writing Skills Of Accounting Students: An Experiment. Journal of College Teaching \& Learning (TLC), 1(1), 4552. https://doi.org/10.19030/tlc.v1i1.1902

Divsar, H., \& Heydari, R. (2017). A Corpus-based Study of EFL Learners' Errors in IELTS Essay Writing. International Journal of Applied Linguistics \& English Literature, 6(3), 143-149.

Ellis, R. and Barkhuizen, G, B, 2005. Analysing Learner Language. Oxford University Press. UK. In Amiri, F. \& Puteh, M. (2017). Error Analysis in Academic Writing: A Case of International Postgraduate Students in Malaysia. Advances in Language and Literary Studies, 8 (4), 141-145

Fareed, M., Ashraf, A., \& Bilal, M. (2016). ESL Learners' Writing Skills: Problems, Factors and Suggestions. Journal of Education and Social Sciences, 4 (2), 81-92.

Huy, N.T. (2015). Problems Affecting Learning Writing Skill of Grade 11 at Thong Linh High School. Asian Journal of Educational Research, 3(2), 53-69.

Hyatt, D. (2013). Stakeholders' perceptions of IELTS as an entry requirement for higher education in the UK. Journal of Further and Higher Education, 37(6), 844-863.

Indriyani, A. (2018). An Error Analysis on Using Cohesive Devices in Students' Narrative Writing Text at SMK Muhammadiyah 2 Metro. Unpublished Udergraduate Thesis, Retrieved from http://repository.metrouniv.ac.id

Khansir, A. A. (2013). Error analysis and second language writing. Theory and Practice in Language Studies, 3(2), 363.

Kharmilah, P., \& Narius, D. (2019). Error Analysis in Writing Discussion Text Made by Students at English Department of Universitas Negeri Padang. Journal of English Language Teaching, 8(3), 327-335.

Lam, Y. W., Hew, K. F., \& Chiu, K. F. (2018). Improving argumentative writing : Effects of a blended learning approach and gamification. Languag Learning \& Technology, 
22(1), 97-118.

Lauder, A. (2008). The Status and Function of English in Indonesia: A Review of Key Factors. Makara, Sosial Humaniora, 12(1), 9-20.

Nartiningrum, N. \& Nugroho, A. (2020). Online Learning amidst Global Pandemic: EFL Students' Challenges, Suggestions, and Needed Materials. ENGLISH FRANCA: Academic Journal of English Language and Education, 4(2), 115-140.

Nugroho, A., Ilmiani, D., \& Rekha, A. (2021). EFL Teachers' Challenges and Insights of Online Teaching amidst Global Pandemic. Metathesis: Journal of English Language, Literature, and Teaching, 4(3), 277-291.

Nugroho, A., \& Rahmawati, A. (2020). "Let'S Write a Caption!": Utilizing Instagram To Enhance Esp Students' Writing Skills. Jurnal Basis, 7(1), 1-13. https://doi.org/10.33884/basisupb.v7i1.1782

Nurhayati, S. \& Nurdini, R.A. (2019). Error Analysis on EFL Students' Independent Writing Task of TOEFL iBT. Elite Journal, 6(2), 159-172.

Rahmatunisa, W. (2014). Problems Faced by Indonesian EFL Learners in Writing Argumentative Essay. English Review: Journal of English Education, 3(1), 41-49.

Richards, J. C., Richards, J. C., \& Renandya, W. A. (2002). Methodology in language teaching: An anthology of current practice. Cambridge: Cambridge university press.

Salima, R. (2012). Measures of Eliminating EFL Students' Errors in Writing. International Conference on Education and Education Psychology (ICEEPSY2012). https://doi.org/10.1016/j.sbspro.2012.11.416

Sulistyo, T., Mukminatien, N., Cahyono, B. Y., \& Saukah, A. (2019). Enhancing learners' writing performance through Blog-Assisted Language Learning. International Journal of Emerging Technologies in Learning, 14(9), 61-73. https://doi.org/10.3991/IJET.V14I09.9535

Taylor, J.R. (1997). An Introduction of Error Analysis: The Study of Uncertainties in Physical Measurement ( 2 ed). California: University Science Boo

To, V., Lê, T., \& Lê, Q. (2013). A comparative study of nominalisation in IELTS writing test papers. International Journal of Innovative Interdisciplinary Research, 1(4), 15-21.

Wu, H., \& Garza, E. V. (2014). Types and attributes of English writing errors in the EFL context-a study of error analysis. Journal of Language Teaching and Research, 5(6), 1256. 